Army watched from across the Vistula. It is true that Polish historiography, both popular and academic, largely ignored the Jewish Holocaust in Poland until the public debate over Jan T. Gross's book. This led to a wave of research and publications, and the German genocide of the Polish Jews is now included in Polish school curricula.

As to the charge of Polish economic collaboration, Martin Dean ("Where Did All the Collaborators Go?") is to be commended for stating what Connelly hints at in his articlethat is, that the scarcity of goods (above all, food) in German-occupied Poland, probably meant "that economic necessity as much as greed encouraged many Poles to acquire former Jewish property" (794) though the best was reserved for ethnic Germans. Regarding another form of "collaboration," Dean notes that several hundred Poles serving in German-controlled local police units were punished after the war, especially those who participated in the German liquidation of Jewish ghettos (796-97). Trials of men accused of collaborating with the Germans were, indeed, held soon after the war in northeastern Poland, but most of the accused were charged with such collaboration in the form of anticommunist resistance while very few were charged with crimes against Jews. Studies and documents of these trials were published in the two-volume work titled Wokót Jedruabmego, edited by Paweł Machcewicz and Krzysztof Persak (2002). Finally, while Dean writes that some Polish "Volksdeutsche" were subject to conscription in the Wehrmacht, he also states that according to the personnel records of the Anders Army (The Polish Second Corps that fought in Italy), many ethnic Poles served in the "German police, Wehrmacht, and even SS forces" (797 and note 15). In fact, tens of thousands of ethnic Poles were conscripted into the Wehrmacht in former (Polish) Silesia and (Polish) Pomerania-formerly part of the German empire-because most were automatically categorized as "Volksdeutsche " a fact Connelly discreetly mentions (776, note 14). It would be interesting to know how many of these men actually served in the German police and SS and who they were. In any case, it was mostly the Volksdeutsche Poles who deserted the Wehrmacht in droves to join the Anders Army in 1943-45, as well as the Polish units fighting in France, Holland, Belgium, and northwestern Germany in 1944-45.

AnNa M. Cienciala University of Kansas

Professor Friedrich replies:

Let me first make it clear that it is NOT my thesis "that the Poles helped the Germans to exterminate the Polish Jews," as Anna Cienciala erroneously asserts. Certain social groups and a number of individuals, however, were ready to cooperate and did in fact cooperate with the Nazi German authorities.

Second, I am more optimistic concerning the possibility of a future scholarly consensus regarding Polish attitudes toward the murder of the Jews by the Nazis. But this will probably not be reached during the lifetime of those who have personally experienced war and occupation. On the other hand, given the Jedwabne controversy, I am not so hopeful about a Polish breakthrough in matters relating to the Holocaust. Except for the writings of Norman Davies, foreign historians and their theses are not popular in Poland. In addition, a homegrown faction of right-wing intellectuals are busily working to replace the discarded communist myths with new ones (see my forthcoming contribution to Polin: Polish Historiography Faces New and Old Challenges, vol. 21 [2008]).

Third, Cienciala misrepresents the numbers given by Lucjan Dobroszycki. From mid-1944, Jewish survivors returned to Poland individually from the territories that were re-Sovietized. Since the end of 1944, former citizens of the Second Polish Republicincluding Jews - were officially "repatriated" from the Ukrainian, Belorussian, and Lithuanian Soviet Republics. Many returned with the Polish People's Army. Consequently, Jews who registered by late 1945 were in large part people who had survived in the USSR. The number I mentioned $(15,000)$ refers to those Jews who survived among the Polish peasants and in little towns; a reliable estimate for the overall number of surviving Jews in the Polish lands may be around 40,000 (see Andrzej Friszke, Polska: Losy państwa i narodu, 1939-1989, 2003, 43).

Fourth, as is well known, Polish resistance was actually passive most of the time; just remember the famous Armia Krajowa slogan: " $Z$ bronią u nogi" (With our rifles at our feet, 
i.e., standing at attention). The decision to launch an uprising in Warsaw was prompted by the installation of the pro-Soviet Lublin committee, and it was directed politically at Stalin's aspirations.

Fifth, although I do not know how John Connelly got the percentages he provides (780), if we assume that they more or less represent historical realities, then, yes, I wish we could have improved the survival rate of Poland's Jews by 5 percent (this is, after all, more than 160,000 people!).

Sixth, extant sources dealing with the participation of Poles in the Nazi genocide have rarely been used by scholars. A rare exception is the first volume of Wokot Jedwabnego, edited by Paweł Machcewicz and Krzysztof Persak (2002) and the article "Udzial Polaków w zbrodniach na Żydach na prowincji regionu świętokrzyskiego" in the new journal Zagłada Żydôw, no. 1 (2005): 114-47. According to authors Alina Skibińska and Jakub Petelewicz, everyday life in the rural areas differed much from the "heroic" picture painted by postwar historians. In fact, people were terrorized - but rather by the Polish Police who acted "very independently" from their Nazi German command; generally, the court files attest to a lot of demoralization.

Furthermore, if we look at the results of new research it seems that it was not simply (and not only) terror that made Poles want to cooperate but the expectation of making a financial gain or of harming someone out of envy (see Barbara Engelking, "Szanowny panie gistapo" Donosy do wtadz niemieckich w Warszawie i okolicach w latach 1940-1941, 2003).

As to Piotr Wandycz's remarks, I would like to restate once again that in my opinion a neutral, scientifically useful "clear definition of collaboration" does not exist. The case of Poland shows that the debate was politically charged at the time and continued to be so in the postwar period. So let us instead deconstruct the concept of collaboration (and its alleged absence!). Historians would do better to integrate the persecution of the Jews into an overall social history of Poland, its regions and localities, during the occupation. Władyslaw Bartoszewski's standpoint is, it seems to me, fairly well known, so I did not feel the need to repeat it. But this does not mean that I do not appreciate his development from a very young adherent of Zofia Kossak and her views on Jewish affairs - to a later advocate of reconciliation between Jews and Poles! Also, the Nazis' persecution of the Roman Catholic Church has been dealt with extensively. The problem is that the picture is incomplete (see Dariusz Libionka, "Antisemitism, Anti-Judaism, and the Polish Catholic Clergy during the Second World War," in Robert Blobaum, ed., Anti-Semitism and Its Opponents in Modern Poland, 2005, 233-64). A reader should also bear in mind that my article was essentially written in 2003 so that one should not expect to find references to texts published simultaneously (like the Polish historians' debate Wandycz recommends).

To sum it up: one gets the impression that the critics quoted above have stopped short in their perception of historical research many years ago. Their arguments do not differ from those put forward by Polish exile historian Kazimierz Iranek-Osmecki in the late 1960s.

Let me end with a remark on Wandycz's charge concerning "mental predispositions." I think historians who reflect on their own position toward the subject of their enquiry do well. As a scholar born, educated, and (partially) trained in Germany, I actually feel the need to explain why I and some of my colleagues are so intrigued by Polish contemporary history and wish to compare developments there to those in Germany (see my "Deutsche Stimmen zur 'Jedwabne'-Debatte in Polen: Eine Bilanz," Zeitschrift für Genozidforschung 6, no. 2 (2005): 8-41). And I concur with John Connelly's appeal to "look beyond Poland"but I insist on doing so only after we have re-examined the state of our knowledge and have formulated the right questions.

\section{Ki.aus-Peter Friedrich} Marburg, Germany

Professor Connelly replies:

Anna Cienciala is onto something when she writes that I dispute Poles' claim to "national pride." My piece was entitled "Why the Poles Collaborated So Little-And Why That Is No Reason for Nationalist Hubris," but I originally wanted to use the word pride rather than hubris. I held back because I imagined that there is something like "healthy national pride." Upon further reflection, however, I am convinced that there is no such thing. 